\title{
JUSTICE IN MANY ROOMS IN SHARIA BANKING DISPUTE RESOLUTION TO ACHIEVE JUSTICE
}

\author{
Nita Triana, Deddy Purwinto \\ Pascasarjana- IAIN-Purwokerto \\ triananita@ymail.com
}

\begin{abstract}
This paper examines the dispute resolution of Sharia Banking. The method is a non-doctrinal legal research using qualitative research and Socio Legal approach. Sharia banking cannot be separated from the problems between the banking and the Customer. This problem is calledproblematic financing. The resolution of problematic financing of sharia banks in litigation is now the absolute authority of the Religious Courts. The downside of litigation settlement usually takes a long time, the need for proof, the cost is quite expensive and the result is winningor lost. Therefore, the settlement of sharia banking is very rarely resolved through litigation. Alternative Dispute Resolution is a choice of dispute settlement chosen by Sharia Banking. The first stage isto carry out negotiation between all parties, namely Banking (lender) and The Customer (Debtor) in the form of warning and guidance. If it does not succeed, there will bedebt restructuration. The second step is mediation, in the form of consultation with third party as a mediator. The mediation determines the rescue process of debt by Banks when a debtor is still unable to return his debt, executed by the bank. According to Marc Galanter these various dispute resolutionsis called justice in many rooms. In Islamic Law it is known as Sulh (peace). However, to a large extent this non-litigation settlement is more satisfactory to both parties in resolving the dispute because it senses fairness and a win-win solution.
\end{abstract}

Keywords: Justice in Many Rooms, Dispute Resolution, Sharia Banking, Sulh

\section{Introduction}

Banking in a country's life is an agent of development. This is because the main function of the banking itself as an institution that collects funds from the community in the form of savings and channeling back the community in the form of credit or financing. This function is commonly referred to as financial intermediation (financial intermediary function). The existence of sharia banking in Indonesia is a manifestation of the wishes of the people who need an alternative banking system that provides banking services that meet the principles of sharia.The development of Islamic banking in Indonesia is so fast and quick, but some people still exist who believe that Islamic banks, conventional banks are using Islamic terms to lure the Muslim community. ${ }^{1}$ In Islamic banking, known as sharia governance, so that the principles of sharia could be optimized. ${ }^{2}$

\footnotetext{
${ }^{1}$ Bagya Agung Prabowo \& Jasri Bin Jamal, Concept And Application Of Akad Wakalah In Murabaha Financing In Islamic Banking (A Comparative Study Between Indonesia And Malaysia), Diponegoro Law Review, April 2017, Volume 02, Number 01, p. 1-14.

${ }^{2}$ Ro'fah Setyowati, Lastuti Abubakar, Nunung Rodliah, Sharia Governance On Islamic Banking: Spiritual Rights Perspective On Consumer Protection In Indonesia, Diponegoro Law Review, April 2017, Volume 02, Number 01, p. 227-244.
} 
Based on Article 4 paragraph 1 of Law Number 21 Year 2008 concerning Sharia Banking. State Gazette of the Republic of Indonesia 2008 Number 94 (hereinafter referred to as the Sharia Banking Law) that conventional commercial banks that also perform sharia activities are called Sharia Business Unit (UUS) and sharia banks also function as Intermediary Institution, From the community and redistributed those funds to the people who need them in the form of financing ${ }^{3}$.

All Sharia banks and Sharia Business Unit are required to have a general policy of fund placement in writing, the definition of investment is the provision of funds, and / or goods, as well as other facilities to customers, which are not contradictory to the Islamic concepts and Islamic banking accounting standards. Investment in Islamic banks and UUS in the form of financing.

Financing is the majority of assets of sharia banks so that the financing must be maintained quality. The basic concept of muamalah transaction in sharia banks are activities that concern human relationships covering political, economic, and social aspects ${ }^{4}$. Muamalah activities that concern the economic aspects include activities to improve the welfare and quality of life, such as: buying and selling, savings and loans, debts, joint ventures, and others.

The development of sharia banking that is so significant of course brings the consequences of the possibility of the occurrence of a problem that can cause disputes in the activities of banking transactions. Disputes arise due to various reasons and problems, mainly because of the conflict of interest between the parties. This condition certainly raises the need for a rule to resolve the dispute ${ }^{5}$.

The birth of Law Number 21 Year 2008 on Banking Sharia further reinforces the dispute settlement mechanism between the bank and the customer. The way of dispute resolution of sharia banking is regulated in Article 55 paragraph (1), (2) and (3). Law Number 21 Year 2008 concerning Sharia Banking.

The explanatory provision of Article 55 illustrates the settlement of disputes concerning the economic activities of sharia banking as if there is dualism ${ }^{6}$, which is resolved in the Religious Courts and the General Courts. But Decision of the Constitutional Court Number 93

\footnotetext{
${ }^{3}$ Ismail. Perbankan Syariah. (Jakarta : Kencana), 2014, p.7

${ }^{4}$ Trisadani P Usanti dan Shomad, Abd. Transaksi Bank Syariah. (Jakarta : Bumi Aksara, 2013). p.130

${ }^{5}$ Ita Tresnawati. Penyelesaian Pembiayaan Bermasalah Melalui Cara Non Litigasi Pada PT. Bank Syariah Mandiri, Tesis, Magister Kenotariatan Universitas Negeri Sebelas Maret, Surakarta, 2015, p. 60

6 .NatsirM. Asnawi.Menyoal Kompetensi Peradilan Agama dalam Menyelesaikan Perkara Ekonomi Syari'ah. (Media Badilag, 2011), p. 4
} 
/ PUUX / 2012 has solved the problem of dualism of dispute settlement in litigation, namely to hand over the absolute authority to solve the dispute over syariah banking litigation to the Religious Court.

Although the explanation of Article 55 Paragraph (2) is deleted, the resolution of a nonlitigation dispute is returned to Article 55 Paragraph (2) which reads: In the event that the parties have agreed to settle the dispute other than as intended in paragraph (1) in the Religious Courts, Carried out in accordance with the contents of the contract and the resolution of alternative disputes such as mediation and arbitration.So after the decision of Court Number 93 / PUUX / 2012, dispute resolution of Islamic banking in litigation handled by the Religious Courts. The non litigation is handled by arbitration and other dispute resolution alternatives.

In the working area of Purwokerto Financial Services Authority, there are 14 (fourteen) syariah banks, and since the resolution of the sharia banking dispute becomes the absolute authority of the Religious Courts, in the Religious Courts of Purwokerto there are only 3 cases of dispute relating to sharia banking. In the location of research that is in PT BPRS (Bank Pembiayaan Rakyat Syariah)Bina Amanah Satria Purwokerto never had a lawyer in Religious Court of Purwokerto. So far, the resolution of non-litigation financing is problematic. For that it is very interesting to investigate about the resolution of problem financing in PT Bank Pembiayaan Rakyat Syariah Bina Amanah Satria and how they solve the problems of banking disputes.

\section{Method}

This study is a non-doctrinal legal research using qualitative research methods and Socio Legalapproach. ${ }^{7}$ Data obtained from field research and literature. The nature of this paper is descriptive. ${ }^{8}$ Descriptive because through writing is expected to be obtained in a systematic and factual overview of the financing dispute resolution in PT Bank Pembiayaan Rakyat Syariah Bina Amanah Satria areusing various models (consultation, negotiation and mediation ) to achieve justice for the parties

\footnotetext{
${ }^{7}$ Sulistyowati Irianto dan Lim Sing Meij. Praktek Penegakan Hukum: Arena Penelitian Sosiolegal yang Kaya. Metode Penelitian Hukum -Konstelasi dan Refleksi. Jurnal JHMP -(Terakreditasi) FH UI. (Jakarta. Yayasan Obor. 2009), p.173.

${ }^{8}$ Corbin J. Strauss and Busir, Qualitative Research, Grounded Theory Procedure and Techniques, (London:

Sage Publication, 1990), p. 19.
} 


\section{Result and Discussion}

\subsection{The Problem of Sharia Financing}

All Islamic banks and Islamic business unit (UUS/ Usaha Unit Syariah) are required to have a general policy of fund investment in writing, the definition of investment is the provision of funds, and / or goods, and other facilities to customers, which are not contradictory to the Islamic concepts and Islamic banking accounting standards applicable. Investment in Islamic banks and UUS in the form of financing.

Financing under article 1 point 25 of the Islamic Banking Act is the provision of equivalent fund or bill in the form of:

1. Shared transaction in the form of mudaraba and musharaka

2. Transaction of leases in the form of ijara or lease purchase in the form of ijarah muntahiyah bit tamlik

3. Sale and purchase transactions in the form of receivables Murabahah, Salam and Istishna

4. A borrow-borrowing transaction in the form of Qardh receivables

5. Hire lease transactions in the form of Ijarah for multilateral transactions.

Based on the approval or agreement between Islamic banks and / or UUS and other parties requiring the party financed and / or given the funding facilities to refund the funds after a certain period in exchange for ujrah, without return or profit sharing 9 .

Financing is the bank's main activity, as a profit-earning business, but it is risk-prone that not only harms banks, but also results in savings and fund users. One of the risks in such financing activities is non-performing financing.

Therefore, all banks are required to have a general policy of fund investment in writing, the definition of investment is the provision of funds, and / or goods or other facilities to customers, which are not contradictory to the Islamic concepts and Islamic banking accounting standards applicable. Investment in sharia bank in the form of financing. Financing under article 1 point 25 of the Islamic Banking Act is the provision of equivalent funds or bills 10

According to Article 23 of Law Number 21 Year 2008 concerning Sharia Banking, Sharia Bank or Sharia/Islamic Business Unit must have confidence in the willingness and capability of the prospective beneficiary customer to repay all obligations in time before disbursing the

${ }^{9}$ Sutan Remy Sjahdeini, Perbankan Syariah. Jakarta : Kencana 2014, p. 57

${ }^{10}$ Abdul Manan, Hukum Ekonomi Syari'ah Dalam Perspektif Kewenangan Peradilan Agama.Jakarta : Kencana, 2012, p.213-214 
funds. To obtain bank confidence in terms of fund disbursement, the Sharia Bank and / or Sharia Business Unit are required to carry out a thorough assessment of the nature, capability, capital, collateral and prospects of prospective recipient customers.

The neglect of bank health signs by banks conducting activities based on sharia principles gives a far greater impact of loss than it is done by a conventional bank. There are at least two reasons why the impact is greater. The first reason for the risks faced by Islamic banks, in terms of financing provided based on mudaraba agreement to its customers far greater than the risks faced by conventional banks that provide credit with a guarantee.

In mudharabah financing, sharia banks as sharia principles should not ask for collateral from customers who are given financing. In other words, syariah banks rely solely on the first way out ${ }^{11}$. The second reason, if there is a failure in financing given to Islamic banks, among others in the form of mudharabah and musyarakah, the customer is not obliged to return the funds.

The purpose of the implementation of prudential principles is none other so that banks are always in a healthy state so that liquid, solvent and profitable (profitable). With the enactment of the principle of caution it is expected the level of public confidence in high Islamic banks so that the public is willing and not hesitate to save funds in the bank. To maintain public trust, sharia banks in channeling their funds in the form of financing should refer to theGeneral Investment Policy(KUPD).

There are several factors causing problem financing as follows:

1. Internal factors (derived from the bank)
a. The lack of understanding of the bank's business
b. Less customer financial evaluation
c. Error setting financing facility (opportunity to do side streaming)
d. The calculation of working capital is not based on the business of the customer
e. Sales projection is too optimistic
f. Sales projections do not take into account business habits and take into account aspects of competitors

g. The guarantees aspect is not taken into account the marketable aspect

h. Weak supervision and monitoring

\footnotetext{
${ }^{11}$ Sutan Remy Sjahdeini.Perbankan Syariah. (Jakarta : Kencana 2014), p.59
} 
i. The occurrence of mental erosion: this condition is affected mutually between customers and bank officials resulting in the process of providing financing is not based on sound banking practices.

2. External factors (derived from outside parties)

a. The character of the customer is not trustworthy (not honest in giving information and report about its activities)

b. Sidestreaming the use of funds

c. Customer management capability is inadequate to lose in business competition

d. The business is running relatively new

e. The customer's business field has been saturated

f. Not able to cope with problems / lack of business master

g. Death of key person

h. Fellow disputes directors

i. The occurrence of natural disasters

j. The existence of government policy: the regulation of a product or sector of economy or industry can have a positive or negative impact for companies related to the industry.

\subsection{Justice in Many Rooms in Sharia Banking Dispute Resolution at PT BPRS Bank Pembiayaan Rakyat Syariah Bina Amanah Satria}

As Galanter discloses ${ }^{12}$, it is justice in many rooms, which means that to settle disputes and seek justice is not only in one room, that is in the State Court, but can be in any room with a different model from the Court. Resolution of sharia banking dispute in PT Bank Pembiayaan Rakyat Syariah Bina Amanah Satria resolved the dispute through non litigation way, that is through internal resolution of syariah bank, mediation and arbitration of sharia, as follows:

1. Consultation (in Syariah Banks)

Each Sharia Bank has its own discretion in solving the dispute settlement. In the implementation there are several things that are taken into consideration as an effort to resolve the dispute, among others through the handling of problem financing, cost approach, psychological approach, approach through third party interference or religious approach.

\footnotetext{
${ }^{12}$ Marck Galanter . Justice in Many Rooms Court, Privat Ordering and Indigenous Law. Article in The Journal of Legal Pluralism. No.19.Thn 1981; p. 17. Satjipto Rahardjo, "Hukum Progresif: Hukum yang Membebaskan”, Jurnal Hukum Progresif, Vol. 1, No. 1, April 2005, p.21-23.
} 


\section{Mediation}

Mediation attempts to resolve disputes through non-litigation means are contained in Law No. 30 of 1999 on Arbitration and Alternative Dispute Resolution through the agreed procedures of the parties that are conducted with the help of a neutral and impartialmediator as a facilitator, in which the decision To reach a fixed agreement taken by the parties themselves, not by the mediator. Therefore, mediation is the process of resolving disputes over negotiations with the help of third parties ${ }^{13}$.

\section{Conciliation and /orArbitration}

Arbitration is an arbitration. Technically the refereeing is a peace court between the parties who agree that the dispute between them be examined and tried by the judge they have appointed and the decision is binding on both parties. In another sense arbitration is a process of dispute resolution outside the court of agreement of the parties concerned by a referee or more $^{14}$

The criteria of wanprestasi in the financing of PT Bank Pembiayaan Rakyat Syariah Bina Amanah Satria are:

a. The late client does not fulfill the agreed obligations without providing clarification to the bank

b. The Customer does not fulfill its obligations in part or all of its obligations to the bank

c. The Customer does something that is prohibited in the contract

When the customer performs a default, it will affect the smoothness of payment obligations and the quality or collectibility of a financing that will ultimately determine the success rate of a bank in the distribution of financing.

Financing at PT Bank Pembiayaan Rakyat Syariah Bina Amanah Satria is categorized as problematic if:

a. The Customer can not repay part or all of it

b. The Customer can not pay its obligations under the contract agreement

c. The Customer does something that is prohibited in the agreement / contract

\footnotetext{
${ }^{13}$ Suyud Margono. ADR dan Arbitrase, Proses Pelembagaan dan Aspek Hukum. (Jakarta : Ghalia Indonesia, 2000), p. 111-113.

${ }^{14}$ Nur Khalidah Dahlan . Arbitration and Mediation Method Applied to Islamic Finance Conflicts in Malaysia. Journal of Social Science Research. Vol 6 No.1. Malaysia. 2015, p. 1154-1155.
} 
If the financing customer is in trouble, PT Bank Pembiayaan Rakyat Syariah Bina Amanah Satria will make efforts to handle problematic financing to obtain optimal results, ie

The first stage of the effort to handle problem financing by banks is to conduct guidance in the form of billing intended to obtain payment in the first opportunity, with minimum cost and still putting good faith in the customer. The minimum requirement to be able to do problematic financing by way of billing is the existence of good faith from the customer, the business activity of the customer is still running, the customer still has the bill or receivable to the cloth person. The things to watch out for in billing are:

a. Make reminder efforts to the customer before payment due

b. Approaching

c. Prevent deliquency prevention

d. Sets the monitoring of the time of collection, among others before the due date, at maturity and after the due date.

Preventive efforts of PT Bank Pembiayaan Rakyat Syariah Bina Amanah Satria in preventing problematic financing include:

a. Be careful in choosing customers, surveys well and thoroughly, whether character, business, guarantee (cover or not), economic ability

b. Maintenance periodically and strictly both installments and business capabilities

c. Promotes two-way communication to help customers.

National Shari'ah Council Fatwa No: 17 / DSN-MUI / IX / 2000 concerning sanctions on capable customers who delay the payment of which contents are:

1. The sanctions referred to in this fatwa are sanctions imposed on LKS to customers who can afford to pay, but procrastinating their payment intentionally

2. Customers who are not / have not been able to pay due to force majeure shall not be subject to sanctions

3. A capable customer who delays payment and / or does not have the will and good faith to pay his debts may be subject to sanctions

4. Sanctions are based on the principle of ta'zir, which aims to make customers more disciplined in carrying out their obligations

5. Sanctions may be fines of a sum of money of which the amount is determined on the basis of the agreement and made when the contract is signed

6. Funds originating from fines are designated as social funds 
The Fatwa of the Nasonal Syari'ah Council can be used as a reference for preventive action for customers who delay the payment of installments so that it can be a concern. In PT Bank Pembiayaan Rakyat Syariah Bina Amanah Satria, the customer who delays the payment by intentionally or not confirmation to the officer is fined and poured in the financing contract so that when the contract is read out the customer can immediately understand and make the attention.

The second stage, if the preventive effort in the form of billing has been done, but the financing remains problematic, then the bank will make efforts to save the financing. The problematic financing disbursement is the bank's efforts to customers who still have good intentions, still have business prospects, performance and ability to pay to minimize bank losses. This rescue action is a model of negotiation between the parties.

Rescue action can be:

1) Rescheduling ie change of repayment schedule or financing period specified in terms of financing contract.

2) Reconditioning (Reconditioning). Changes in part or all of the terms of the financing as long as they are not related to the maximum financing ceiling / balance, between ain include changes in payment schedule, timeframe and so on.

3) Restructuring. Rearrangement is a change in financing requirements that are not limited to rescheduling or recoditioning, among others by making additional funding of bank financing facility by converting financing akad.

Third stage, the handling of non-performing financing that can not be done through a rescue in the form of restructuring, must be done financing problem settlement step, so that within certain period of problem financing can be solved in whole or in part. The settlement of non-performing financing is conducted through liquidation, namely the sale of collateral as settlement of liabilities to the bank, either by the client or the owner of the collateral with the consent and under the supervision of the bank, usually involving a neutral third party. The model used is banking mediation.

Of the three efforts to handle problematic financing in PT Bank Pembiayaan Rakyat Syariah Bina Amanah Satria purwokerto handling through liquidation or sale of collateral is a last resort in the resolution of troubled financing after the collection and rescue efforts.

The settlement of non-performing financing through the way of sale of collateral will be implemented with the following considerations: 
1). Financing has entered the collectibility of substandard, doubtful or loss and good faith customers less so that other efforts are not successful

2). Business customers are not there / prospect so that the ability to pay less even almost none

Based on the above description of the process stages of non-litigation financing settlement through non-litigation method in PT Bank Pembiayaan Rakyat Syariah Bina Amanah Satria implementation of problem financing resolution dispute resolution mechanism conducted internally bank through regular billing efforts and liquidation / sale of collateral by prioritizing the rules of musyawarah In accordance with the applicable Standard Operating Procedures or in accordance with internal policies in handling non-performing financing.

\subsection{The Concept of Peace in Alternative Dispute Resolution of Sharia Banks}

After seeing the process of resolving customer disputes with defaults in Islamic banking above, if viewed from the perspective of Islamic law, alternative dispute resolution outside this court is in accordance with the teachings of Islam, namely resolving disputes in a peaceful manner. The first peaceful effort is consultation, a personal process between one particular party called the client/nasabah and another party called a consultant, who gives his opinion to the client to fulfill his needs. In this case the client is not bound or obliged to fulfill the opinion of the consultant, but consultation with the consultant provides very useful knowledge for the client / client. In the case of banks, these consultants are usually banks who are very understanding of the problems faced by their customers. In consultation there is usually clarification of data from each party and talking about what will be done.

The next peaceful effort is negotiation. Negotiation is a form of resolving disputes between the parties themselves, without assistance from other parties by means of deliberation or negotiation to find a solution deemed fair by the parties. The results of the negotiations are in the form of a compromise resolution. The agreement of the negotiations is legally binding because there is a principle of pacta sun servanda. An agreement that has been agreed upon by both parties is as binding as the law.

Consultation and Negotiation are efforts to resolve disputes in consultation. Deliberation is a common human nature and includes the stability of a society. Deliberation is not a goal in its origin, but it is stated in Islam to realize justice among humans, and also to choose the best case for them, as a manifestation of the shari'ah goals and laws, therefore deliberation is one of 
the branches of branches of religious shari'a, following and submitting to the principles of religious shari'a.

Allah says. "Meaning: And deliberate with them in that matter" (Ali-Imran: 158) That is so, so that the Muslims consult in various affairs of their lives as long as the Prophet sallallaahu 'alaihi wa sallam deliberates with his friends. And the Muslims practice this teaching is more important. Therefore, the verse came down which made a sign of the Muslims about deliberation. God says. "Meaning: As for their affairs (decided) by deliberation between them" (Ash-Syuura: 38) Meaning: "The Muslims did not decide the problem with their own opinions until they deliberated and agreed on one problem. That is because of the strength of their attention and vigilance, honestly their brotherhood in faith, and mutual love between them because of Allah "If this is the case, then deliberation is one of the foundations of Islam in society and politics.

Abu Hurairah said: "I did not see someone who had more deliberations (musyawarah) with his friends from the Prophet sallallaahu 'alaihi wa sallam. And deliberation also took place among the companions of the Prophet, including the words of Umar bin Khatthab Radhiyahu 'anhu: "Al-Khilafah is a deliberation among the six companions of the Prophet whose Prophet sallallaahu' alaihi wa sallam died, while he sallallaahu 'alaihi wa sallam was in peace them'.Ali Syuura (The Experts Asked for Their Opinion to Consult). The syuura experts are "Ahlul halli wal aqdi" (those who are experts in solving problems) or those chosen by Waliyul Amri (Head of State) to consult/discussion/deliberations (musyawarah).

The purpose of Deliberation/musyawarah: (1). Produce opinions and solutions to get to the solution in the most important form. (2). The guarantee of safeguarding the public good, and the unavailability of human rights if realized in a perfect form. (3). Realizing justice among humans (4). The ability of this manhaj (deliberation) to absorb disputes, keep the shock that is sometimes produced due to disagreements of opinion and opposition. (5). Develop, use and manage abilities in a special and successful form, resulting in discovery along with its development.

The third stage in the settlement of Islamic banking disputes is the mediation model, which is a negotiation process between the customer and Islamic banking, by presenting a neutral third party. These third parties are usually parties to OJK (Financial Services Authority). Mediation known and applied in Indonesia as regulated in Article 1 point 7 of the Regulation No. 1 of 2008 "Mediation is a way of resolving disputes through the negotiation process to obtain agreement of the parties with the assistance of a mediator. In other words, mediation is 
one form of inter-negotiation two individuals or groups involving a third party with the aim of helping to achieve a compromise resolution ".

Good Paster ${ }^{15}$, one of the conflict resolution activists stated that "mediation" is a process of negotiating problem solving where an outside party is impartial, neutral, does not work with the disputing parties, helps them reach an agreement resulting from satisfactory negotiations. Meanwhile, according to Laurenc Boulle, mediation is a decision making process in wich the parties are assisted by the mediator, the mediator attempts to improve the process of decision making and to assist the parties to reach an out come to wich of them can assent.

Huala Adolf ${ }^{16}$ in the "Introduction to Mediation" citing Moor C. W, essentially mediation is a negotiation involving a third party who has skills in efficient mediation procedures and can help in hostile conditions to coordinate their activities to be more efficient in bargaining system, if there is no negotiation ... there is no mediation.

The mediator encourages and facilitates dialogue, helps some parties clarify their needs and part of their desires, prepares tips, helps some parties to rectify some inequalities of views and work for one that can be accepted by some parties in a binding settlement. If there is a match between several parties to the dispute then a memorandum is made containing several agreements that have been reached.

The mediator as a dispute resolution driver must be big-hearted, patient, resilient and inspire both the character of the parties and the problems faced, the mediator's expertise in delivering the parties to find a middle way to resolve their disputes is the main condition that cannot be bargained again. The offer of a concept that touches the heart is needed at this level of mediation, because the purpose of mediation is not only to end disputes but also to build the weakness of the parties without anyone feeling defeated, so that the final mouth of mediation which is outlined in the form of peace is the best choice of parties based on mutual willingness.

A mediator basically has a tendency to use an interest-based negotiation, in which case the needs of all parties can be represented. Mediation and negotiation are not two separate systems but are more concerned with negotiations facilitated by a neutral third party. Although substantial negotiations differ from mediation, it is often stated that there is no mediation if there is no negotiation. Therefore negotiation is a value that needs to be mediated, so the first

\footnotetext{
${ }^{15}$ Gary Goodpaster, Panduan Negosiasi Dan Mediasi (Seri Dasar Hukum Ekonomi), (Jakarta: ELIPS , 1999), p. 241-242. Nita Triana, Reconstructing Sharia Economic Dispute Resolution Based on Indonesian Muslim Society Culture. Ijtimā 'iyya: Journal of Muslim Society Research, Vol. 2(1).2017,p. 102

${ }^{16}$ Adolf Huala, Hukum Penyelesaian Sengketa Internasional, (Jakarta, Sinar Grafika. 2006) ,p.26-27
} 
party offer and the price of the concession will also be very sure of the final outcome of the negotiation (mediation) ${ }^{17}$.

The willingness of the parties becomes important to produce the agreed values of justice in response to the resolution of the dispute that befell them, in addition to the draft material of peace that will be offered by each party which is no less important is the awareness of the parties to reach a pleasant final resolution. To realize this as the parties must also have a patient intention, willing to listen to all parties, analyze and digest all input so that the answers delivered are truly solutions that come out of the heart, which in turn to carry out the peace that is forgiven through mediation does not produce new tension.

Mediation is different from litigation that wants to get the final results in accordance with the applicable law, in contrast to counseling because the foundation of mediation is not based on psychological aspects and behavior. Likewise, mediation differs from arbitration, where the arbitrator is appointed to give the final provision. Enactment of Mediation in the justice system in Indonesia is based on PERMA Number 1 Th. 2008.

The purpose of applying the Supreme Court regulation is a very progressive legal umbrella and guarantees the parties are not injured due to mediation settlement, and mediation is not only to cut the long road of a judicial process that is not necessarily satisfying to all parties, but more important is to create togetherness and satisfaction for all parties based on the values of justice, humanity and civilized solutions ${ }^{18}$.

There are many methods offered by the concept of Islam in realizing peace wherever and in any field, so that anyone who is determined to resolve conflict by means of mediation transferred from Islamic teachings is a powerful choice, just how we respond to and realize that concept into our daily lives day because the method of one mediator with another mediator is very different in style and application, what else the parties faced are also varied. This should not be a negative assessment as long as all the efforts taken by the mediator are only in the frame of a mutually beneficial resolution.

\footnotetext{
${ }^{17}$ James .A Wall, John B Stark and Rhetta L Standifer. Mediation ,A Current Review and Theory Development. Journal of Conflict Resolution. Vol.45. Issue 3. 2001,p.371.

${ }^{18}$ Philippe Nonet, \& Selznick, Philip, Law and Society in Transition, Toward Responsive Law, (N.Y. : Harper Colophon Books, 1973), p.14-15.

See: Boaventura de Sousa, Toward a New Common Sense: Law, Science and Politics in the Paradigmatic Transition, (N.Y. : Routledge), 1995, p.223.
} 
Furthermore, the last effort of the settlement of the dispute in the PT BPRS Bina Amanah Satria purwokerto is the sale of collateral or customer assets that are pledged as collateral to banks. Usually the model used is conciliation, namely with the mediator who can decide how many loans must be repaid and what can be handled by the sales guarantee. This model is similar to Arbitration, which is by presenting the referees who are deciding, but the path taken in PT BPRS Bina Amanah Satria Purwokerto does not reach the arbitration body.

This model in Islam is commensurate with the tahkim model. Tahkim in the sense of Arabic, is "to give a decision to someone and accept the decision." In terms of the term: two people or more judge someone between them to settle the dispute and apply shara law to their dispute "then the tahkim position is lower than judicial standing. because the judge has the right to examine each other's complaints that cannot be done by a Muslim, because that Abu Yusuf did not allow us to hold something against the tahkim. other than that the judge given by muhkkam only applies to those who accept the verdict, while the judge's decision must apply even if it is not accepted by the person concerned.

This form of tahkim has been known by Arabs in the mass of jahiliyah. Hakam must be heard. If something goes wrong, the parties go to the judge. Most disputes that occur among Arabs are about, Who is better at praising his class and defeating other groups . Often members of the community are right when something happens between them, or face an absurd thing, go to people who are considered clever, without pressure from the law, to ask for opinions. They do not know the religious law against the events they face. And they feel there is no need to complain their case to judges who are thirsty to obey their decisions, because in addition to the judiciary there are tahkim and ifta .

According to Al-Munjid's dictionary ${ }^{19}$, the tahkim is to appoint someone as a referee or peace agent. Whereas Salam Madkur stated in the book Al-Qadha Fil Islam that the term tahkim means to appoint someone or more as a referee or peace agent by two or more people who are in dispute in order to settle the case which they have peacefully divided. Whereas the term now tahkim can be translated as arbitration, and the person acting as the referee is called arbitrator or hakam. 2. Tahkim Legal Basis The legal basis for tahkim, is the word of Allah Q.S. An-Nisa verse 35. Meaning: "If you are worried that there is a dispute between the two, then send a Hakam from a male family and a Hakam from a female family. QS. Al-Hujurat: 9

${ }^{19}$ Ibid. Hais Wahed, 2015 
The nature and form of settlement of disputes carried out by the tahkim institution are more likely to choose the method of family and peace. In Surah An-Nisa verse 127 it is stated that "peace is better". Inviting reconciliation means inviting to goodness. The model for solving such cases has become a commitment of friends. For example, Umar Ibn Khathab, in completing every case always always reminded to prioritize "the way of peace". In one lie alqadha Risalat affirmed: "peace is permissible among Muslims, except peace that justifies something that is forbidden or forbids anything that is lawful. Invite the disputants to peace ". In this connection, there is an expression that describes the high value of peace: Al-Shulhu Sayyid Al-ahkam.

If the approach by means of kinship and peace is always offered and becomes the model of the tahkim institution in resolving disputes, there will be no visible impression of winning and losing, which can bequeath the rust of heart, jealous envy, resentment, hatred and hostility between them. All parties together become the winning party because it is decided through the agreement of the parties together. Thus, the decision of the arbitral institution seems to be more friendly, which can reassure and cool the parties' hearts.

Unlike the official judicial products that have the binding power and force (fiat execution), the strength of the products of the tahkim institution is a matter of debate. However, most of the Islamic jurists (followers of Hanafi priests, followers of Imam Hambali, Followers of Imam Maliki, and the majority of followers of Imam Shafi'i) consider that the decision of the institution of tahkim directly is binding on the parties. The binding itself has taken place when the parties elect and appoint the authority of tahkim as the mediator to resolve their dispute. Whereas according to a small number of followers of Imam Syafi'i, the products of the tahkim institution are not binding and have no legal force, except if they have prior approval from the parties, so in practice they are more fundamental to the willingness and legal awareness of the parties.

Hakam's decision is not the same as the qodhi (judge) decision. The verdict given by hakam, must be carried out by the person concerned, according to ahmad and abu hanifah and according to a narration from asyafi'y. But according to other history, the law given by hakam does not have to be obeyed by the person concerned. if a hakam has given a verdict, then they go again to file the case to another hakam, then this other hakam gives putsan also by not knowing the first and final decision is contrary to the first decision, then if the matter is submitted to the judge, let the judge apply the law according to his opinion. If a case has been decided by someone hakam then submitted to the judge, then the judge may justify the decision 
of hakam if it is in accordance with his school. And may he cancel the breakdown if it goes against his school (Mazhab).

In Al Mughni, Ibn Qudamah explained that the law stipulated by law applies in all kinds of cases, except in the fields of marriage, li'an, qadzaf, and qishash. In matters only the ruler can decide. Ash Syafi'y followers have two opinions on this issue. Ibn Farhun in Tabshirah said, that the judge's decision was valid in the fields of property, not applicable in the field of criminal, li'an, qishash, qadzaf, talak or determining descent. The estimated parties may refuse the judge's decision, before the judge issues his decision. The judgments are seen as muqolid which is followed by both parties because they may impeach (dismiss) the mukallad, before the mukallad overthrows the law., then the decision applies, cannot be canceled again.

Some scholars believe that there is no need for willingness from the parties until when carrying out their respective statements on a judge, then one of them wants to withdraw his student before deciding the judge, then the judge can continue to decide the law and the law. According to the legitimate opinion, each party can withdraw the award, as long as there is no decision.

According to the diligent opinion of the Malik school (Mazhab Malik), there is no need for continuous willingness from both parties until the law is given. But if both of them withdraw their decrees before the law is determined then the withdrawal is justified and cannot again decide the case. Judges may hear witnesses' statements and can also decide cases by beating, also with pledges, because they are laws that are in accordance with the law. If the defeated party denies the existence of a pledge even though the information is sufficient, then he keeps the case away from the judge, then the judge may accept what has been determined by the judge as long as the litigant is still in the position to judge him or her he has no right to decide the case, the judge does not have to heard by the judge.

The various models adopted to settle disputes at PT BPRS Bina Amanah Satria Purwokerto are essentially the resolution of disputes in a peaceful manner. This concept of peace which is known in Islam as the Sulh concept, is a process of dispute resolution where the parties agree to end the case peacefully (Islah). The Qur'an recommends that the parties to the dispute take the path of sulh in resolving disputes both in court and outside the court.

Sulh provides an opportunity for the parties to think about the best way to resolve disputes, and they are no longer tightly attached to the submission of evidence. Suggestions from the Qur'an and the hadith of the Prophet chose Sulh as a means to settle disputes which are based on the consideration that, sulh can satisfy the parties and no party feels victorious or 
loses in resolving their dispute. Therefore the judge must always strive for the parties to the dispute to take the path of peace (Islah).

Ash-Shulh came from the Arabic people which meant peace, the cessation of strife, the cessation of war. In scientific knowledge, ash-shulhu is classified as one of the contracts in the form of an agreement between two disputants or litigants to complete a dispute between the two. In the terminology of knowledge of fiqh ash-shulhu has the understanding of an agreement to get rid of problems between fellow opponents so that the facility reaches an agreement on some people who are at odds ${ }^{20}$.

In Ash-shulhu there are many meanings, namely: All parties that make peace in Islamic law are called musalih, while the disputed issue is called musalih'anhu, and the actions done by one of the parties to different parties to establish a conflict / dispute are named with musalih'alaihi or also called badalush shulh.

Peace in Islamic law is recommended. Because, with peace will also avoid the destruction of surrender (affection relationship) all hostility between the parties to the dispute will be ended. Regarding the law of shulhu, it is also revealed in various prophetic hadith, one of which is narrated by Ibn Hibban and Imam Tirmizi which means "peace is permissible among the Muslims, except peace justifies the haram or forbids the haram ${ }^{21}$.

As well as some Muslims (who make peace) depends on their criteria (which have been agreed), except the prerequisites that forbid the lawful or justifies the illegitimate (HR Ibn Hibban and Turmuzi) ". A particularly observable message from the above hadith is that peace is something that is permissible as long as it is not used for some things that are contrary to the basic Islamic teachings. For the acquisition and realization of peace, even though it is not justified to change the legal provisions that have been firm in Islam. Some Muslims who participate in peace must pay attention so that the peace agreement does not contain a number of things that face the reversal of the law; the halal is haram or vice versa.

Rukun Shulhu Regarding the pillars of peace, namely: Mushalih, Mushalih'hu, Mushalih 'alaih, and Shigat ijab and Kabul among the two parties who carried out the peace contract. If the pillars are fulfilled, peace between the parties to the dispute is already underway. By itself,

\footnotetext{
${ }^{20}$ Aliflanya Maghfirah Arisandy,Dwi AR..Sulh in Islamic Criminal Law as The Form of Restorative Justice. A New Framework In Indonesian Criminal Law. Scientific Corporations International Journal of Law and Politics, Vol 2 Issue 1 Juli 2016), p.225.

${ }^{21}$ Aseel Al Ramahi. Sulh: A Crucial Part of Islamic Arbitration. Law Society and Economiy Working Paper .London School .2008, p. 4.
} 
from the peace agreement, a legal bond is born, which is the same as the parties to fulfill / fulfill the articles of the peace agreement ${ }^{22}$.

In the matter of the existence of a third party it is very important to bridge the parties to the dispute ${ }^{23}$. The parties generally need the help of others to find the right solution for their dispute resolution. The third party is very instrumental in carrying out facilitation, negotiation, mediation and arbirase among the parties to the dispute. facilitation, negotiation, mediation, and arbirase are technical forms of dispute resolution using the Sulh pattern. This sulh pattern can be developed in alternative solutions to disputes outside the court such as mediation (wasatha), arbitration (tahkim), and others. This pattern is very flexible and gives parties and third parties the flexibility to formulate options and alternative dispute resolution. Sulh is a means of bringing about overall peace and prosperity. Sulh is not done if it brings damage and loss to humans.

The process of resolving disputes or conflicts that were carried out by the Prophet both after and before the Prophet Muhammad became an apostle can be found in the event of the relaying of Hajar aswad and the treaty of Hudaibiah. In the Hudaibiah agreement there were several important points that were successfully carried out by the apostle including: The Apostle succeeded in inviting the Quraysh to negotiate the shirt and produce an agreement. This is an extraordinary victory for the Muslims considering that the people of Mecca who had insulted and harmed the Muslims began to sit with the Prophet at a negotiating table. The values that can be drawn from the Hudaibiah agreement based on the principle of mediation include the attitude of negotiation, the attitude of take and give compromise, positioning the parties and respecting the agreement.

Now, basically, ash-shulhu consists of four types, one of which is the type that is commonly carried out in Sharia financial dispute, namely Peace on some parties who do transactions (peace in mu'amalat), namely to make peace in matters that are related to disputes -(disputes that occur in mu'amalat problems).Ash sulh model in Islamic financial dispute resolution using mediator, and this mediator does not act as a judge who imposes his justice mind, nor does he take a binding summary like arbitrarily but empowers several parties to ensure the solution of what they want.

\footnotetext{
${ }^{22}$ Wahbah Zuhaili , Al Fiqh al Islam wa Adillatuhu Juz IV (Damaskus Syria : Dar El Fikr, 2005), p.18

${ }^{23}$ Hais Wahed. Sulh: Its Application in Malaysia. Journal of Humanities and Social Science (IOSR_JHSS) Vol 20.Issue 6 Ver 11 June 2015), p.71-72
} 
Galanter tells us about the complexity and relativity of the Court, and which therefore can not be monopolized by the State Court. Courts can be present in many spaces. Courts established by the community can work more effectively than the state courts, which are bound to so many procedures. Galanter said: It would be disturbing to conclude that talking about access to justice requires people to bring their problems to the State Court. This is too narrow. Courts should be expanded to include a number of different agencies that also remedial agencies.

\section{Conclusion}

Based on the results of research and analysis it can be concluded that:

The process of financing problem resolution in PT BPRS Bank Pembiayaan Rakyat Syariah Bina Amanah Satria is conducted in many rooms in Banking with different model, that is the first stage using internal negotiation and cosultation model of bank through coaching and billing effort, second phase is rescheduling, reconditioning, And restucturing) and the third stage in the form of efforts to settle non-performing financing (liquidation) by selling collateral. At the stage of sale of collateral still put forward the rules of musyawarah and use a third party that is neutral (mediation) and Conciliation .The resolution of non-performing financing through non-litigation method of PT BPRS Bank Pembiayaan Rakyat Syariah Bina Amanah Satria is in accordance with the provisions in Law no. 21 of 2008 concerning Sharia Banking, the Fatwa of the National Sharia Council and other regulations related to prioritizing the principle of deliberation in the resolution of non-litigation problematic financing.

The implementation of non-litigation financing resolution in sharia banking is a cheap, simple and quick process option rather than dispute settlement through costly, time-consuming and costly litigation process that will pose a risk. Completion of this model is the resolutin of disputes established by the community based on their needs. Which by Galanter referred to as justice in many rooms.In Islamic Law it is known as Sulh (peace). Qur'an and the hadith of the Prophet chose Sulh as a means to settle disputes which are based on the consideration that, sulh can satisfy the parties and no party feels victorious or loses in resolving their dispute. Therefore the judge must always strive for the parties to the dispute to take the path of peace (Islah).

\section{References}


Adolf, Huala, (2006). Hukum Penyelesaian Sengketa Internasional, Jakarta, Sinar Grafika.

Asnawi, M.Natsir, (2011). Menyoal Kompetensi Peradilan Agama dalam Menyelesaikan Perkara Ekonomi Syari'ah. Media Badilag,

Galanter Marck, (1981). Justice in Many Rooms Court, Privat Ordering and Indigenous Law. The Journal of Legal Pluralism. No.19.Thn 1981.

Goodpaster Gary, (1999). Panduan Negosiasi Dan Mediasi (Seri Dasar Hukum Ekonomi), Jakarta: ELIPS .

Irianto Sulistyowati dan Lim Sing Meij, (2009) Praktek Penegakan Hukum: Arena Penelitian Sosiolegal yang Kaya. Metode Penelitian Hukum -Konstelasi dan Refleksi. Jurnal JHMP -(Terakreditasi) FH UI. Jakarta: Yayasan Obor.

Ismail, (2014). Perbankan Syariah. Jakarta : Kencana.

Khalidah.Dahlan Nur, (2015). Arbitration and Mediation Method Applied to Islamic Finance Conflicts in Malaysia. Journal of Social Science Research. Vol 6 No.1. Malaysia.

Maghfirah.Aliflanya Arisandy, Dwi AR, (2016). Sulh in Islamic Criminal Law as The Form of Restorative Justice. A New Framework In Indonesian Criminal Law. Scientific Corporations International Journal of Law and Politics.Vol 2 Issue 1 Juli.

Manan, Abdul, (2012). Hukum Ekonomi Syari'ah Dalam Perspektif Kewenangan Peradilan Agama.Jakarta : Kencana.

Margono, Suyud, (2000). ADR dan Arbitrase, Proses Pelembagaan dan Aspek Hukum. Jakarta : Ghalia Indonesia.

Philippe Nonet, \& Selznick, Philip, (1973). Law and Society in Transition, Toward Responsive Law, N.Y. : Harper Colophon Books,.

Prabowo Bagya Agung \& Jasri Bin Jamal, (2017). Concept And Application Of Akad Wakalah In Murabaha Financing In Islamic Banking (A Comparative Study Between Indonesia And Malaysia), Diponegoro Law Review, April 2017, Volume 02, Number 01

Rahmani.Al Ascel, (2008). Sulh: A Crucial Part of Islamic Arbitration. Law Society and Economiy .Working Paper .London School.

Rahardjo, Satjipto "Hukum Progresif: Hukum yang Membebaskan”, Jurnal Hukum Progresif, Vol. 1, No. 1, April 2005. 
Setyowati Ro'fah, Lastuti Abubakar, Nunung Rodliah, (2017). Sharia Governance On Islamic Banking: Spiritual Rights Perspective On Consumer Protection In Indonesia, Diponegoro Law Review, April 2017, Volume 02, Number 01.

Sjahdeini, Sutan Remy, (2014). Perbankan Syariah. Jakarta : Kencana.

Sousa, Boaventura de Sousa, (1995). Toward a New Common Sense: Law, Science and Politics in the Paradigmatic Transition, N.Y. : Routledge,

Strauss and J Corbin, Busir, (1990). Qualitative Research, Grounded Theory Procedure and Techniques, London: Sage Publication.

Tresnawati, Ita, (2015). Penyelesaian Pembiayaan Bermasalah Melalui Cara Non Litigasi Pada PT. Bank Syariah Mandiri, Tesis, Magister Kenotariatan Universitas Negeri Sebelas Maret, Surakarta.

Triana, Nita, (2017). Reconstructing Sharia Economic Dispute Resolution Based on Indonesian Muslim Society Culture. Ijtimā'iyya: Journal of Muslim Society Research, Vol. 2(1)..

Usanti P, Trisadani dan Shomad, Abd, (2013). Transaksi Bank Syariah. Jakarta : Bumi Aksara. Wahed.Hais, (2015). Sulh: Its Application in Malaysia. Journal of Humanities and Social Science IOSR_JHSS, Vol 20.Issue 6 Ver 11 June.

Wall.A James, John B Stark and Rhetta L Standifer, (2001). Mediation ,A Current Review and Theory Development. Journal of Conflict Resolution. Vol.45. Issue 3.

Zuhaili Wahbah, (2005). Al Fiqh al Islam wa Adillatuhu Juz IV, Damaskus Syria : Dar El Fikr..

Undang-Undang Nomor 21 tahun 2008 tentang Perbankan Syariah

Undang-Undang Nomor 3 Tahun 2006 tentang Peradilan Agama.

Undang-Undang Nomor 30 Tahun 1999 tentang Arbitrase dan Alternatif Penyelesaian Sengketa 